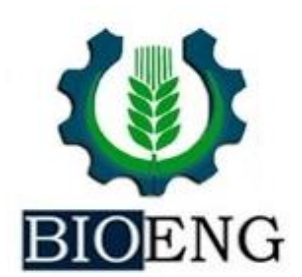

\section{DEVELOPMENT AND EVALUATION OF THE CLIMATIC CONDITIONS INSIDE A SUSTAINABLE BACKYARD POULTRY BUILDING}

\author{
A.R. Adejuwon ${ }^{1}$, R. Olomo ${ }^{1}$, F.R. Falayi ${ }^{1}$, A.O. Jongbo ${ }^{1 *}$
}

${ }^{1}$ Department of Agricultural and Environmental Engineering, School of Engineering and Engineering Technology, Federal University of Technology, PMB 704, Akure, Ondo State, Nigeria.

Article history: Received 11 August 2020; Received in revised form 19 September 2020; Accepted 21 September 2020; Available online 30 September 2020.

\begin{abstract}
Small scale backyard poultry buildings, which could be of any shape and design, are very important and every household in Nigeria should embrace. However, it is difficult for most households to plan and design appropriate buildings for their poultry birds. This study was carried out to design a building which could allow birds to exhibit their natural behaviours without being exposed to hazards and predators. The building with dimensions $2.8 \mathrm{~m}$ long, $2.3 \mathrm{~m}$ wide and $1.9 \mathrm{~m}$ height at the front and $1.3 \mathrm{~m}$ at the back was developed using local materials. The building comprised of resting room and a free space for poultry to exhibit their natural behaviours such as dust bathing, wing flapping and preening. There were perches inside the building were birds could roost at night. The indoor and outdoor climatic conditions (air temperature and air relative humidity) were evaluated. The result of the study showed that the highest mean indoor air temperature $\left(30.60{ }^{\circ} \mathrm{C}\right)$ and highest mean indoor air relative humidity $(83.88 \%$ ) were obtained in the afternoon and night respectively. The lowest mean indoor air temperature $\left(24.23{ }^{\circ} \mathrm{C}\right)$ and mean indoor air relative humidity $(66.64 \%)$ were obtained in the night and afternoon respectively. The building was considered affordable (\$280.00) and suitable for poultry grown for egg and meat production in the tropical humid climate.
\end{abstract}

Keywords: Air temperature; Air relative humidity; Poultry; Sustainability; Tropical humid climate.

\title{
DESENVOLVIMENTO E AVALIAÇÃO DAS CONDIÇÕES CLIMÁTICAS DENTRO DE UM EDIFÍCIO DE AVES SUSTENTÁVEL
}

\section{RESUMO}

Aviários domésticos em pequena escala, de qualquer formato e desenho, são muito importantes, e todas as famílias na Nigéria deveriam ter acesso. No entanto, é difícil para a maioria das famílias planejar e projetar aviários apropriados para suas aves. Este estudo foi realizado para projetar uma construção que pudesse permitir que as aves exibissem seus comportamentos naturais sem serem expostas a perigos e predadores. O edifício com dimensões de 2,8 $\mathrm{m}$ de comprimento, 2,3 $\mathrm{m}$ de largura e 1,9 $\mathrm{m}$ de altura na frente e 1,3 $\mathrm{m}$ de

\footnotetext{
*aojongbo@futa.edu.ng
} 
fundo foi desenvolvido com materiais locais. A edificação é composta por sala de descanso e espaço livre para que as aves exibam seus comportamentos naturais como banho de poeira, batimento de asas e alisamento. Haviam poleiros dentro do prédio onde as aves podiam pousar à noite. Foram avaliadas as condições climáticas internas e externas (temperatura e umidade relativa do ar). Os resultados do estudo mostraram que a maior temperatura média do ar interno $\left(30,60{ }^{\circ} \mathrm{C}\right)$ e a maior umidade relativa média do ar interno $(83,88 \%)$ foram obtidas no período da tarde e à noite, respectivamente. As menores médias de temperatura do ar interno $\left(24,23{ }^{\circ} \mathrm{C}\right)$ e umidade relativa do ar interno $(66,64 \%)$ foram obtidas no período da noite e da tarde, respectivamente. O prédio foi considerado acessível (US \$280,00) e adequado para criação de aves para produção de ovos e carne em clima tropical úmido.

Palavras-chave: Temperatura do ar; Umidade relativa do ar; Aves; Sustentabilidade; Clima tropical úmido.

\section{INTRODUCTION}

Poultry meat production across the world has greatly increased compared to other types of meat during the past decade. The potential growth, short time of production and affordability of birds are directly related to its value in human diets.

Annually, over ten billions of poultry meat are globally produced (Mench, 2018). However, some factors namely; poor poultry production as a result of diseases, poor ventilation and inadequate floor space (Baracho et al., 2019) are inhibiting the growth of the poultry meat industry in the humid tropical climate such as Nigeria.

Other factors that had been shown to influence poultry production include genetic strain, climatic conditions (Baracho et al., 2019), stocking density (Jones, et al., 2005), price of feed (Adebayo \& Adeola, 2005), diet, veterinary care (Cernicchiaro et al., 2016), and environmental enrichment (Riber, et al., 2018).

Small-scale poultry production, which comprises mainly the chickens, is mostly practised in the rural areas, which are categorised as poor-resource regions (Wong et al., 2017). It contributes greatly to the poverty alleviation and food security of the rural areas (Alders \& Pym, 2009).

The rural dwellers engage in smallscale poultry production to provide meat and eggs for their scarce animal protein and also for sale to meet essential family needs which include children school fees, medicine and clothing (Alders \& Pym, 2009; Wong et al., 2017).

However, it could be difficult to meet all their essential needs due to some constraints such as inappropriate building design, diseases, feed price fluctuations, inadequate biosecurity, predators and climatic conditions (Blatchford, 2017; Wong et al., 2017). The climatic condition to which the poultry is subjected could pose severe problems for them (Jacob et al., 2017).

The conditions could adversely affect the feed intake, egg production most especially during hot weather periods (Jacob et al., 2017). Therefore, developing appropriate backyard poultry buildings could reasonably minimise the impact of harsh weather on poultry.

Generally, in Nigeria, almost all households practice small-scale poultry production (Chia \& Ugwuishiwu, 2014).

However, they either raise the poultry in buildings not properly designed to meet the necessary requirements of the birds or leave the poultry to scavenge for feed and also sleep anywhere they found (Adeyemo $\&$ Onikoyi, 2012). The reason for such an approach, allowing birds to scavenge for feed by themselves, could be related to the unattractive economic incentive of the 
backyard poultry production (Adeyemo \& Onikoyi, 2012).

Although Mikulski et al. (2011) had indicated some advantages of free ranged birds such as higher nutrient intake, low feeding cost, higher omega-3 fatty acids, vitamins in eggs and poultry meat, and the taste of the poultry meat, it is still necessary to develop a backyard poultry building that would consider all the

\section{MATERIALS AND METHODS}

\section{Design details and component description of} the poultry building.

The conceptual design of the poultry building was carried out with the AutoCAD 15. The building comprised of a frame, ventilation ports, floor space for birds, perches, resting box and the nest boxes. The dimensions of the frame were $2.8 \mathrm{~m}$ long, $2.3 \mathrm{~m}$ wide and $1.9 \mathrm{~m}$ height at the front and $1.3 \mathrm{~m}$ at the back (Figure 1).

The floor space was designed as $0.33 \mathrm{~m}^{2}$ per bird (Poultry production, 2013). A staircase with a few steps was designed to provide birds with an opportunity to assess the next boxes and the resting box. The ventilation rate required inside the building was estimated as $0.43 \mathrm{~m}^{3} \mathrm{~s}^{-1}$ using the equation for ventilation rate in Jongbo and Falayi (2013).

There were five nesting boxes with total dimensions of $1.6 \mathrm{~m}$ long, $0.19 \mathrm{~m}$ wide, and $0.12 \mathrm{~m}$ height (Figure 2). The resting box for the birds was designed with a wire floor and manure collector of dimensions $2.15 \mathrm{~m}$ by $0.6 \mathrm{~m}$ for easy maintenance (Figure 3). Two perches inside the resting room were constructed with $0.02 \mathrm{~m}$ diameter galvanised pipe essential needs of the poultry for their optimum production.

Therefore, the objectives of the study were to (1) design and develop a backyard poultry building for small-scale households in Nigeria and; (2) evaluate the environmental conditions inside and outside the building.

placed across the room. They were located at $0.45 \mathrm{~m}$ above the wire floor and spaced $0.40 \mathrm{~m}$ apart. The galvanised pipe was considered suitable as it could be cold and provide leg cooling for birds during the day and night (Gates et al., 2014).

The beams, trusses and the surface cover of the poultry building were made of Bilinga wood (Nauclea diderrichii), locally known in Nigeria as Opepe. The mechanical properties of the wood include; crushing strength, static bending strength and modulus of elasticity of $63 \pm 7 \mathrm{MPa}$, $95 \pm 11 \mathrm{MPa}$ and $14660 \pm 1934 \mathrm{MPa}$ respectively (Cirad, 2012). The physical properties of the wood include; specific gravity, coefficient of volumetric shrinkage, fibre saturation point of $0.76 \pm 0.07, \quad 0.55 \pm 0.05 \%$ and $25 \%$ respectively (Cirad, 2012).

The wood could be used without preservatives as it has a high resistance to fungi, wood borers and termites (Cirad, 2012). The roof was made of aluminium zinc, installed at a slope of $15^{\circ}$.

The total cost of construction of the poultry building was approximately 280 US dollars (\$280.00) 


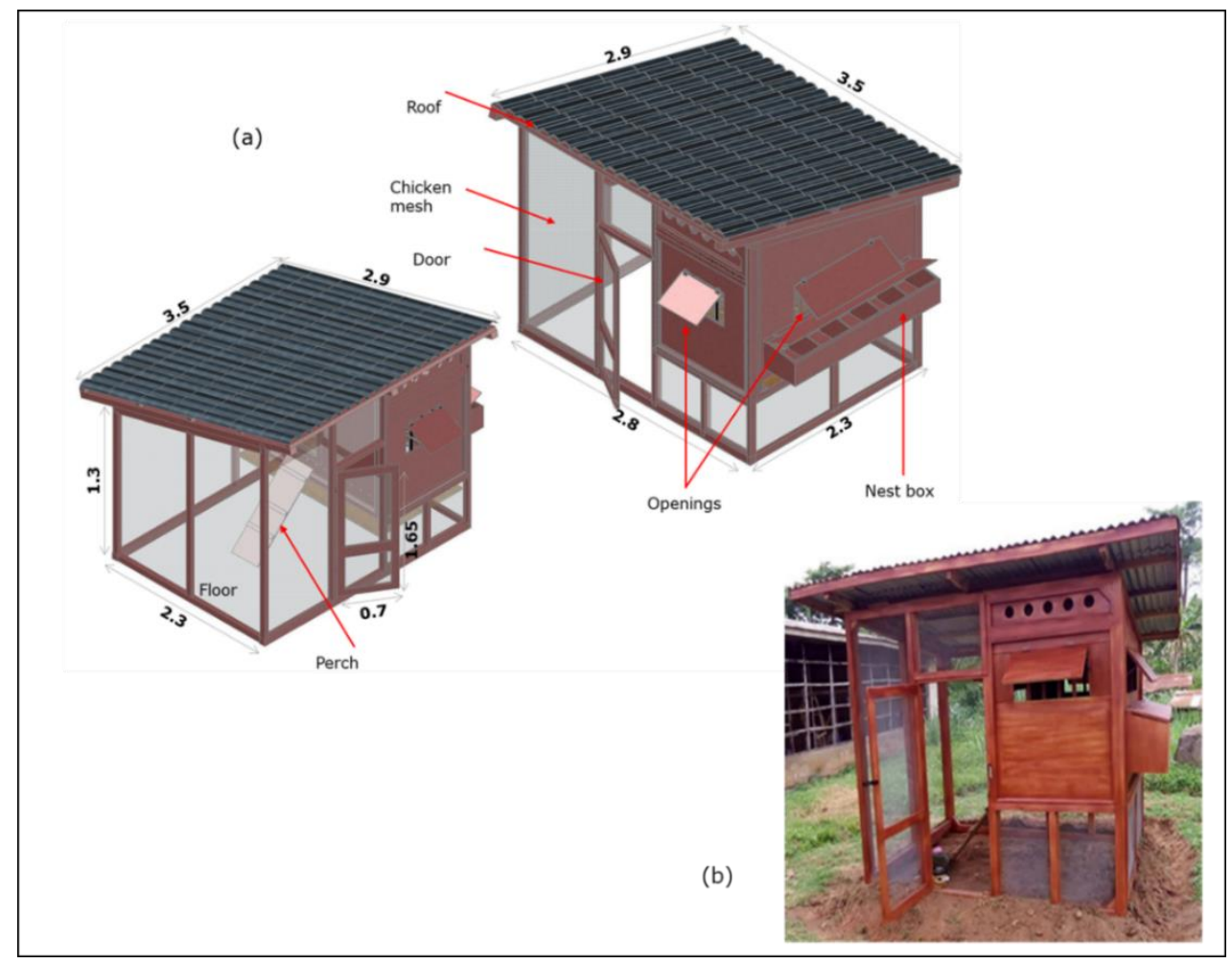

Figure 1. The (a) isometric view and (b) pictorial view of the backyard poultry building. All dimensions in metres.

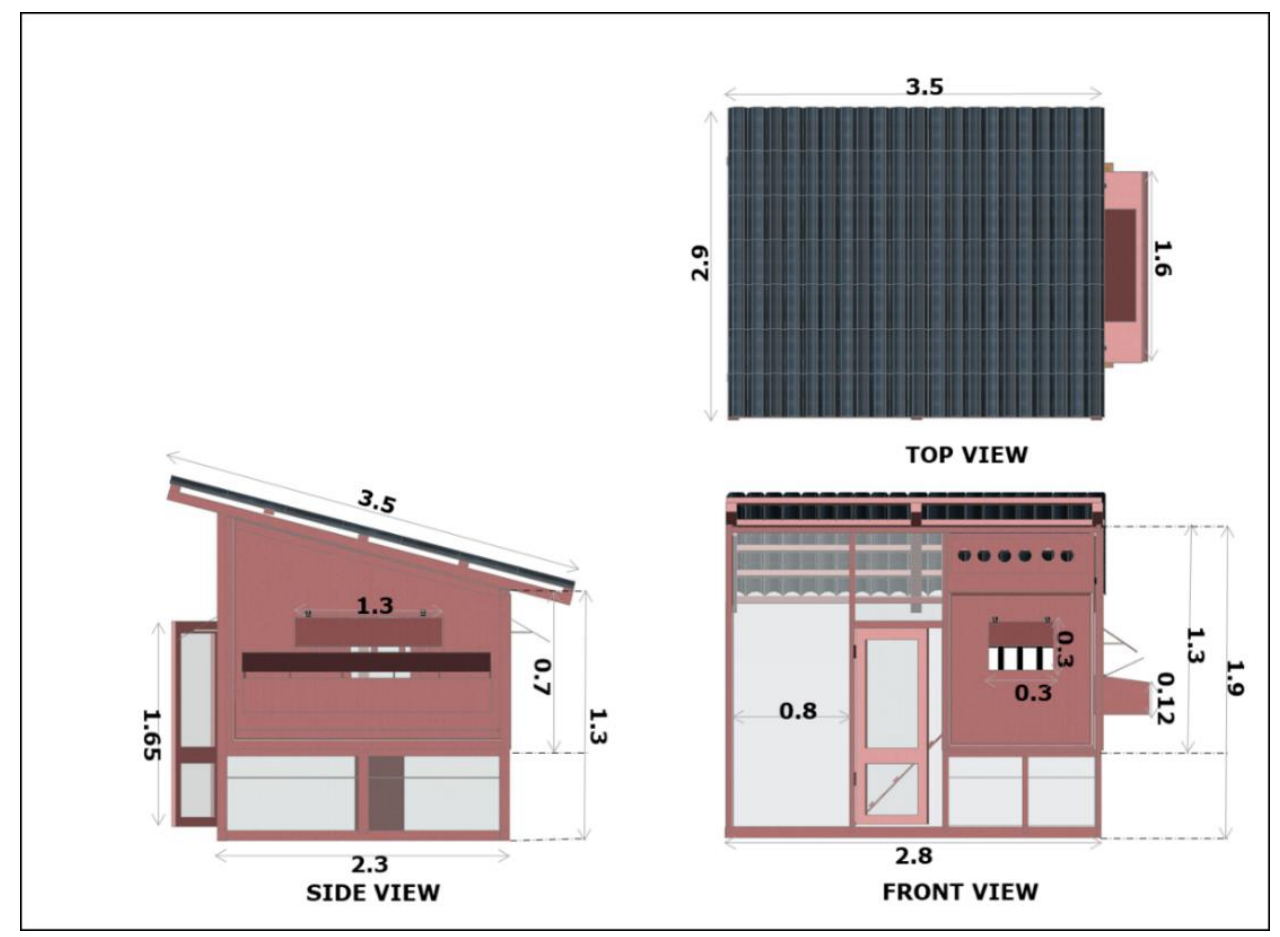

Figure 2. Orthographic view of the backyard poultry building. All dimensions in metres. 


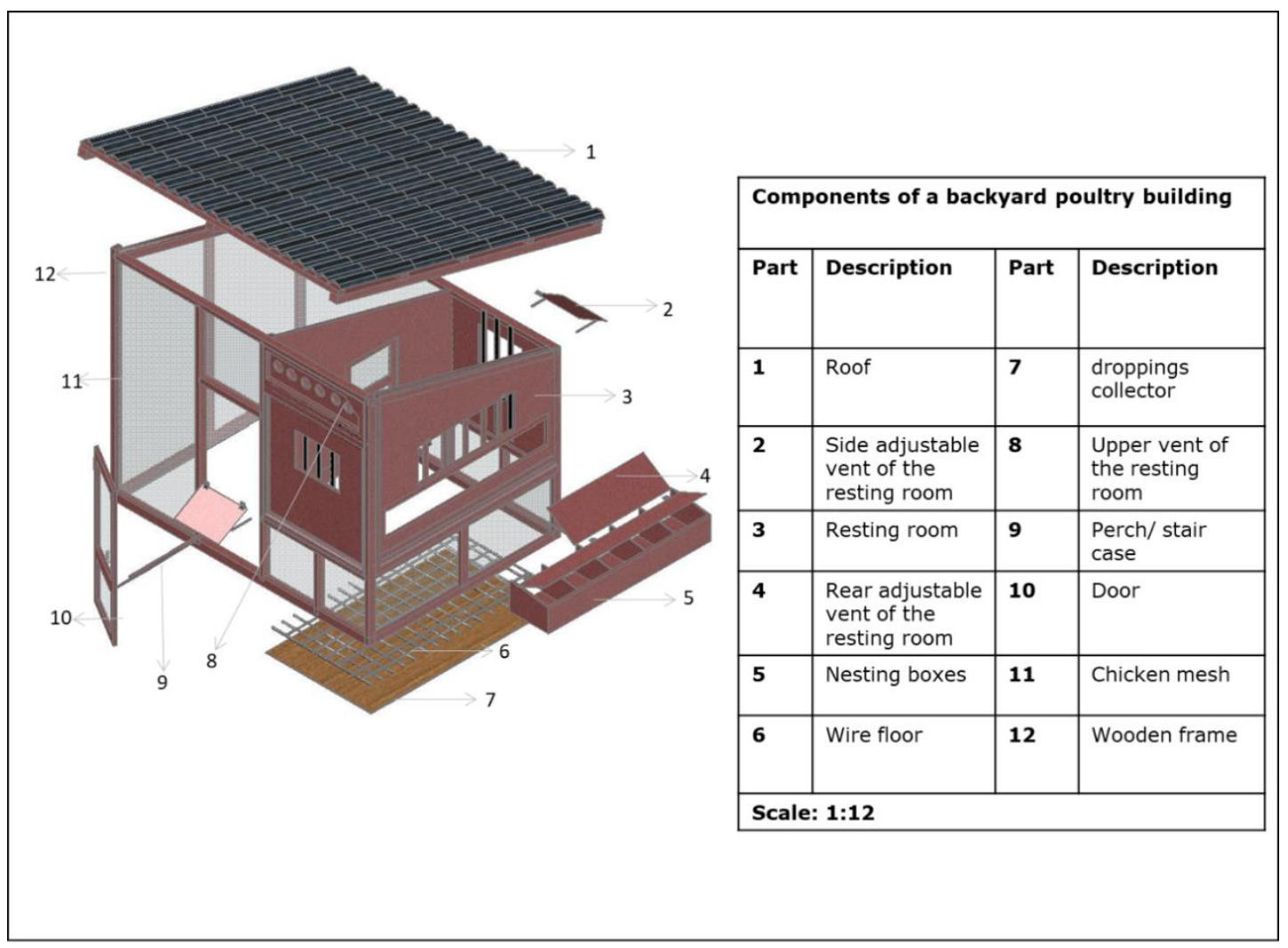

Figure 3. Exploded view of the backyard poultry building.

\section{The experimental site, instrumentation and data acquisition.}

The poultry building was constructed and evaluated at Poultry Research Farm of the Federal University of Technology, Akure, Ondo State, Nigeria. The location is on the latitudes $7^{\circ} 17^{\prime} 03^{\prime \prime} \mathrm{N}$ to $7^{\circ} 19^{\prime} 06^{\prime \prime}$ $\mathrm{N}$ and longitudes $5^{\circ} 07^{\prime} 02^{\prime \prime} \mathrm{E}$ to $5^{\circ} 09^{\prime} 05^{\prime \prime}$ E. It falls into the humid tropical climate region, having a high temperature, ranging from $22^{\circ} \mathrm{C}$ to above $30^{\circ} \mathrm{C}$ and two major seasons namely; rainy season (April to October) and dry season (November to March). Its annual rainfall is about $2400 \mathrm{~mm}$.

The air temperature and the air relative humidity data inside and outside the building were monitored and logged using a CS215 temperature and relative humidity probe in a weather station and a DHT22 temperature and relative humidity sensor respectively. The measurements from the CS215 temperature and relative humidity probe were recorded using a Campbell CR200X-series data logger (Campbell Scientific, Inc, USA) installed in the weather station.

The CS215 temperature and relative humidity probe has accuracies of $\pm 0.9{ }^{\circ} \mathrm{C}$ and $\pm 4 \%$ for temperature and relative humidity respectively and measurement ranges of -40 to $70{ }^{\circ} \mathrm{C}$ and 0 to $100 \%$ for temperature and relative humidity respectively.

The DHT22 temperature and humidity sensor module was built and calibrated for this study (Figure $4 \mathrm{~b}$ ). The DHT22 sensor has accuracies of $\pm 0.5{ }^{\circ} \mathrm{C}$ and $\pm 2 \%$ for temperature and relative humidity respectively, resolutions of $0.1{ }^{\circ} \mathrm{C}$ and $0.1 \%$ for temperature and relative humidity respectively and measurement ranges of -40 to $80{ }^{\circ} \mathrm{C}$ and 0 to $100 \%$ for temperature and relative humidity respectively. 


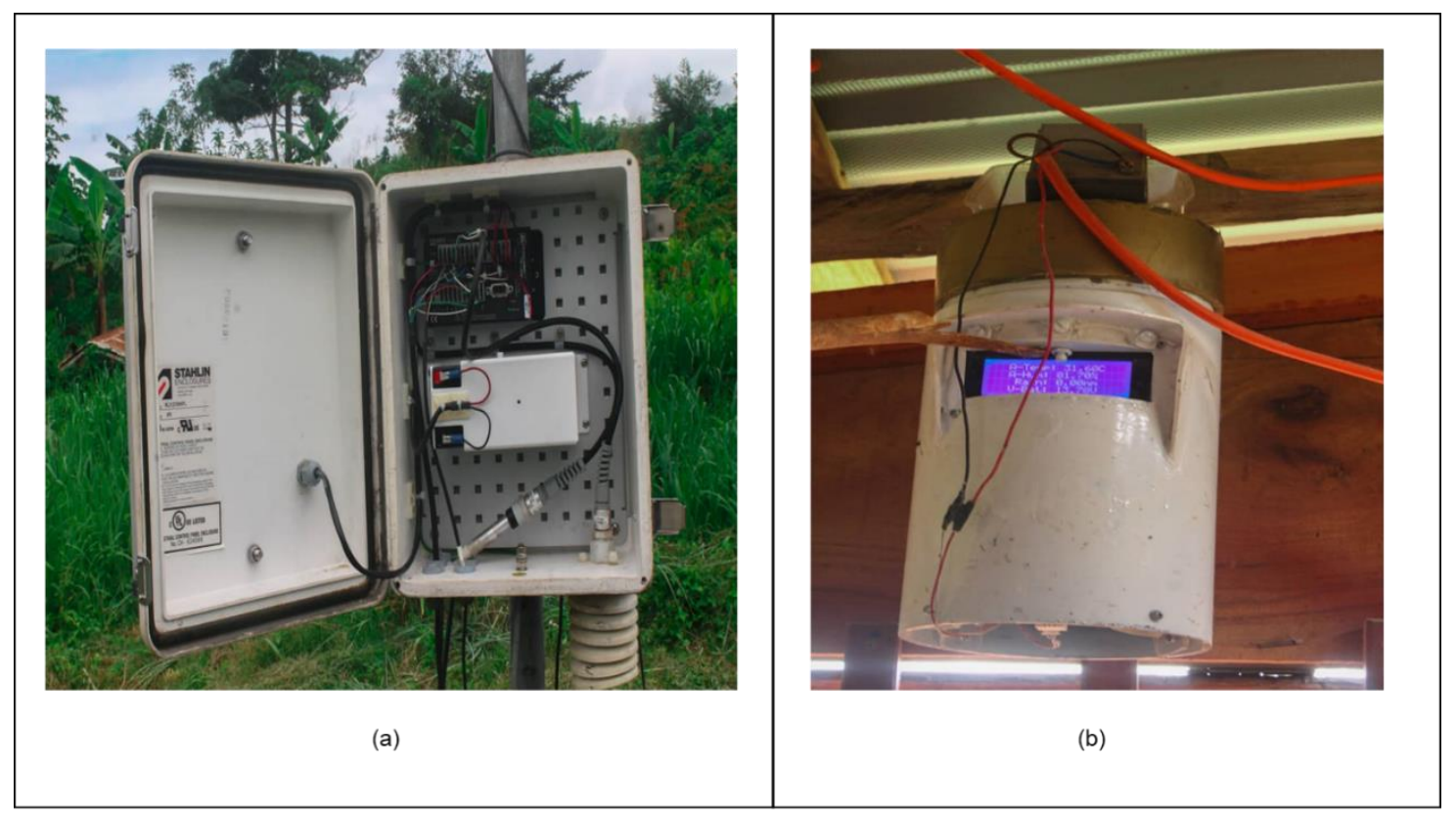

Figure 4. Measurement of air temperature and air relative humidity using (a) CS215 probe and Campbell CR200X-series datalogger (b) DHT22 sensor module.

The weather station, comprising CS215 temperature and humidity sensor and the Campbell CR200X-series was installed at about $5 \mathrm{~m}$ away from the poultry building to measure and $\log$ the outdoor condition of the building.

The data logger was programmed using a PC200W software (Campbell Scientific Inc, USA) to log the air temperature and air relative humidity data from the CS215 probe.

The DHT22 sensor module was installed inside poultry building at $0.6 \mathrm{~m}$ above the wire floor to measure the indoor air temperature and the indoor air relative humidity in the building.

The module was programmed using Arduino UNO and an SD memory card was installed in the module for storing the air temperature and air relative humidity data. The data from the two sensors (CS215 probe and DHT22 sensor) were continuously recorded and logged at one hour interval for 25 days.

\section{Data analysis}

The data obtained were processed into day periods namely; morning $(0600 \mathrm{H}$ to $1100 \mathrm{H})$, afternoon $(1200 \mathrm{H}$ to $1700 \mathrm{H})$, evening $(1800 \mathrm{H}$ to $2300 \mathrm{H})$ and night $(0000 \mathrm{H}$ to $0500 \mathrm{H})$ using Microsoft Excel Professional Plus 2016 and were analysed using JMP ${ }^{\circledR}$ Pro 13.0.0 (SAS Institute Inc, USA).

Some data analyses such as t-test, ANOVA and Turkey-Kramer HSD were conducted. The t-test analysis was carried out to determine the level of significance between the indoor and outdoor conditions during the afternoon. The ANOVA analysis was conducted to examine the effect of day periods on the thermal conditions inside the building at different day periods.

Finally, a Turkey-Kramer HSD analysis was carried out to compare the means of the indoor and outdoor conditions (air temperature and air relative humidity) with respect to the day periods. The data analyses were carried out at a significance level of $5 \%$. 


\section{RESULTS AND DISCUSSION}

\section{Air temperature}

The indoor and outdoor air temperature of the poultry building were evaluated. The results of the average air temperature inside and outside the poultry building, over the period of 25 days are shown in Figure 5.

The average indoor air temperatures in the morning, afternoon, evening and night were, $25.35{ }^{\circ} \mathrm{C}, 30.60$ ${ }^{\circ} \mathrm{C}, 26.77{ }^{\circ} \mathrm{C}$ and $24.23{ }^{\circ} \mathrm{C}$ respectively (Figure 5). The mean outdoor air temperature in the morning, afternoon, evening and night were $29.02{ }^{\circ} \mathrm{C}, 32.47$ ${ }^{\circ} \mathrm{C}, 27.56{ }^{\circ} \mathrm{C}$ and $26.71{ }^{\circ} \mathrm{C}$ respectively. It could be observed in Figure 5 that the air temperature inside the building, in some of the days, were about $22{ }^{\circ} \mathrm{C}$ at all periods of the day. These were the days when short period of sunshine was experienced.

The result of the ANOVA analysis indicated that there was a significant difference $(\mathrm{p}<0.0001)$ between the mean indoor air temperatures of the day periods.

However, further analysis conducted using Turkey-Kramer HSD showed that there was no significant difference $(p=0.084)$ between the mean indoor air temperatures in the morning and evening. In addition, Turkey-Kramer HSD also indicated that there was no significant difference $(\mathrm{p}=0.245)$ between the mean indoor air temperatures in the morning and night.

A t-test analysis was conducted for better understanding of the difference between the indoor and outdoor conditions during the afternoon. The result showed that there was a significant difference $(\mathrm{p}=$ 0.017) between the mean indoor and outdoor air temperatures.
It could be generally observed from Figure 5 that the indoor condition of the building was lower than that of the outdoor except in the evening where there were overlaps. In the night, outdoor air temperature was a few degrees higher than that of the indoor.

Similar results had been reported by Teye et al. (2008) who indicated that indoor air temperature could be a few degree higher or lower than the outdoor air temperature of an uninsulated animal buildings.

The air temperatures obtained in the building were higher than the recommended air temperatures for mature poultry in CIGR (1984) and Holik (2015) for tropical climate. This indicates that poultry raised in this building could be subjected to high indoor air temperatures during the afternoon periods (Jongbo, 2020).

At high air temperature, most especially in the afternoon, there is a possibility for the feed intake, performance and feed conversion rate of the birds to reduce (Gu et al., 2008). The fluctuation in the indoor air temperature is directly related to the period of exposure of animal buildings to the sunshine (Herbut et al., 2015).

This study, in conjunction with other work (Al-Aqil et al., 2009), has shown that it could be difficult to maintain an optimum air temperature inside the naturally ventilated poultry buildings in the tropical climate countries.

According to Schauberger et al. (2019), the constant increased air temperature, in the tropical climate, could cause an increase in heat stress as a result of anthropogenic warming. 


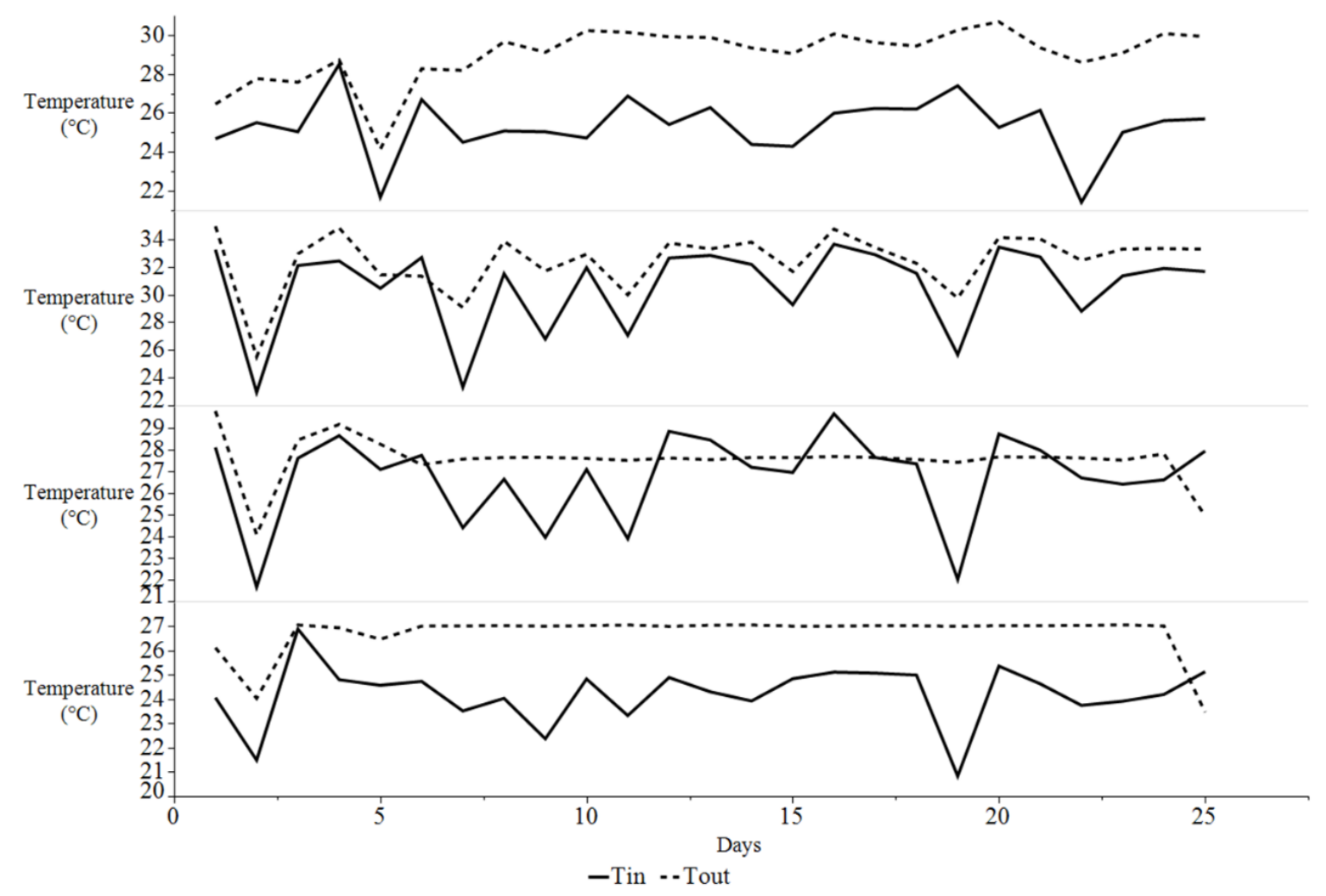

Figure 5. Air temperature inside (Tin) and outside (Tout) the poultry building

\section{Relative humidity}

The results of the air relative humidity obtained inside and outside the poultry building are shown in Figure 6 . The results showed that the average indoor air relative humidity of $81.85 \%, 66.64 \%$, $76.72 \%$ and $83.88 \%$ were obtained in the morning, afternoon, evening and night respectively.

The mean outdoor air relative humidity of $78.01 \%, 65.35 \%, 81.76 \%$ and $84.44 \%$ were measured in the morning, afternoon, evening and night respectively. As it could be noted in Figure 6 , air relative humidity was mostly greater than $80 \%$ during the morning and night but mostly lesser than $80 \%$ during the afternoon and evening during most of the days.

The ANOVA analysis indicated that there was a significant difference $(\mathrm{p}<$ 0.0001 ) between the mean indoor air relative humidity of the day periods. However, the analysis conducted with Turkey-Kramer HSD which compared the means of the air relative humidity of the day periods showed that there was no significant difference $(p=0.448)$ between the mean indoor air relative humidity in the morning and night. A t-test analysis was carried out to determine the difference between the mean indoor and outdoor air relative humidity in the afternoon and the result indicated that there was no significant difference $(\mathrm{p}=0.542)$ between the mean indoor and outdoor air relative humidity during the afternoon.

It could be observed in Figure 6 that the air relative humidity inside the building is higher than that of the outdoor air relative humidity. The higher indoor air relative humidity obtained inside the building could be as a result of the lower air temperature inside the building (Jongbo, 2020).

As also indicated by Pedersen et al. (1998) the latent heat loss which greatly depends on the air relative humidity could be reduced when the indoor air relative humidity is high $(80 \%)$. Similarly, high 
air relative humidity could aggravate the negative effect of high air temperature on poultry (Gu et al., 2008).

High air relative humidity inside animal building, if not properly controlled, could significantly contribute to the fast spread of an influenza virus (Lowen et al., 2007).

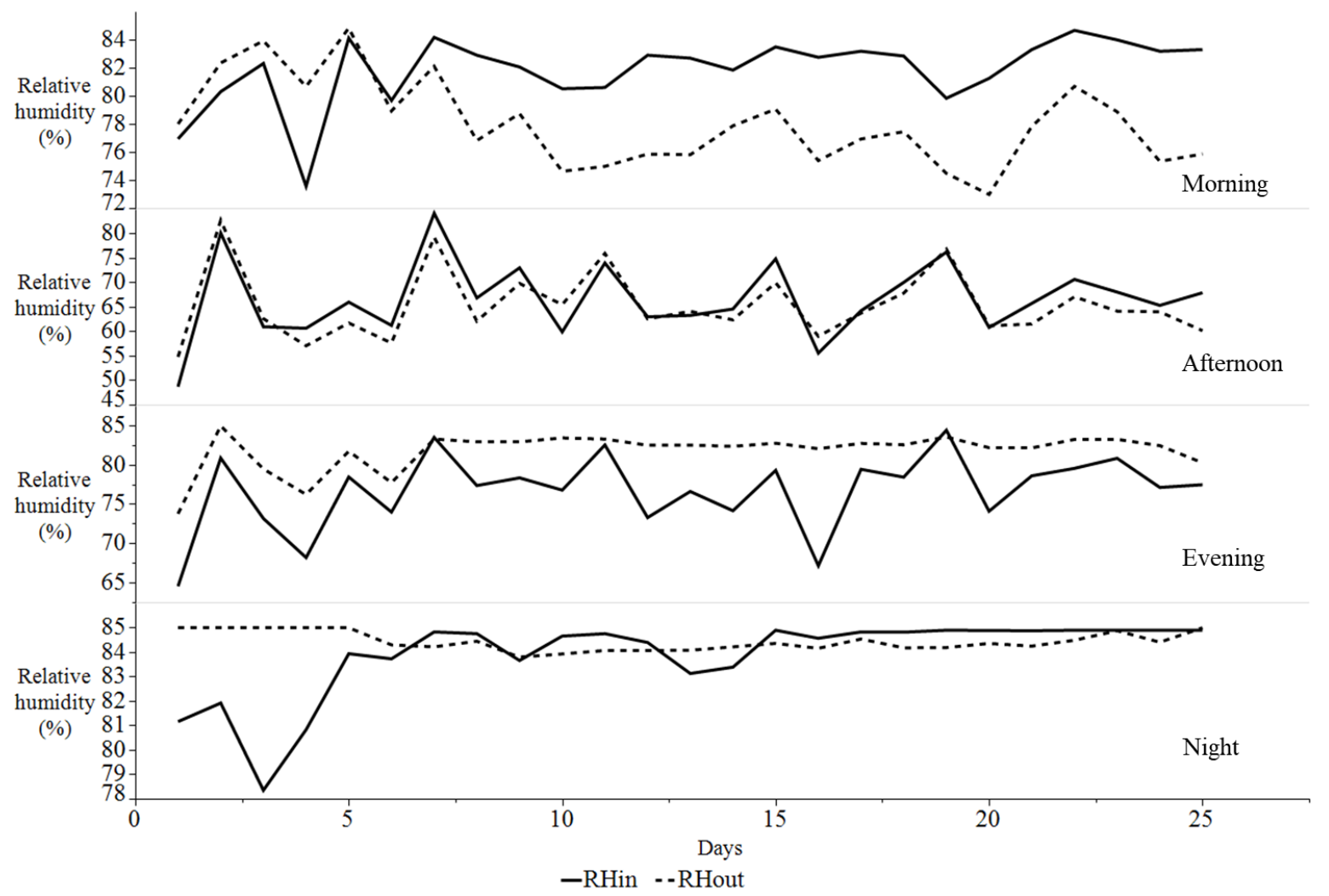

Figure 6. Air relative humidity inside (RHin) and outside (RHout) the poultry building

\section{CONCLUSION}

The indoor and outdoor of a sustainable backyard building developed for households in Nigeria was evaluated.

The building is affordable and all materials used are readily available locally. The evaluation of the climatic condition, both inside and outside showed that the building could provide suitable conditions for the enclosed animals in tropical humid climate.

However, the conditions were discovered to be above the recommended climatic conditions for poultry despite the fact that the climatic conditions could be lessened when lesser sunshine is experienced.
With the constant effect of global warming on the climatic conditions of livestock buildings, there is possibility for the air temperature and air relative humidity of the animal building to keep increasing.

Therefore, to minimise the impact of hot weather on the welfare and performance of livestock, there is a need for a provision of cooling fans for providing cooling for the poultry during hot periods.

Further study would include testing the building with live domestic fowls and the effect of the building stocked with poultry on the indoor climatic conditions would be evaluated. 


\section{ACKNOWLEDGEMENTS}

There was no financial support for this study. However, the author would like to appreciate the staff of the Animal

\section{DECLARATION OF INTEREST}

The authors declare that they have no known competing financial interests or personal relationships that could have

\section{REFERENCES}

ADEBAYO, O. O.; ADEOLA, R. G. Socio-Economics Factors Affecting Poultry Farmers in Ejigbo Local Government Area of Osun State. Journal of Human Ecology, 18(1), 39-41, 2005. https://doi.org/10.1080/09709274.2005.11 905804

ADEYEMO, A. A.; ONIKOYI, M. P. Prospects and challenges of large scale commercial poultry production in Nigeria. Agricultural Journal, 7(6), 388-393, 2012. Retrieved from http://docsdrive.com/pdfs/medwelljournals /aj/2012/388-393.pdf

AL-AQIL, A.; ZULKIFLI, I.; SAZILI, A. Q.; OMAR, A. R.; RAJION, M. A. The effects of the hot, humid tropical climate and early age feed restriction on stress and fear responses, and performance in broiler chickens. Asian-Australasian Journal of Animal Sciences, 22(11), 1581-1586, 2009.

https://doi.org/10.5713/ajas.2009.90021

ALDERS, R. G.; PYM, R. A. E. Village poultry: Still important to millions, eight thousand years after domestication.

World's Poultry Science Journal, 65(2), 181-190, 2009.

https://doi.org/10.1017/S00439339090001 17

BARACHO, M. S.; NÄÄS, I. DE A.; LIMA, N. D. S.; CORDEIRO, A. F. S.; MOURA, D. J. Factors affecting broiler
Research and Teaching Farm, Federal University of Technology, Akure, Nigeria for their technical support.

appeared to influence the work reported in this paper.

production: A meta-analysis. Revista Brasileira de Ciencia Avicola, 21(3), 2019. https://doi.org/10.1590/1806-90612019-1052

BLATCHFORD, R. A. Backyard flock production. Advances in Poultry Welfare. Elsevier Ltd. 2017

https://doi.org/10.1016/B978-0-08100915-4.00016-6

CERNICCHIARO, N.; CORBIN, M.; QUINN, M.; PROUTY, F.; BRANINE, M.; RENTER, D. G. Meta-analysis of the effects of laidlomycin propionate, fed alone or in combination with chlortetracycline, compared with monensin sodium, fed alone or in combination with tylosin, on growth performance, health, and carcass outcomes in finishing steers in. Journal of Animal Science, 94(4), 1662-1676, 2016. https://doi.org/10.2527/jas.2015-0086

CHIA, V. D.; UGWUISHIWU, B. O. The trends and tides of poultry farm building in Makurdi , Benue State, Nigeria. American Journal of Engineering Research (AJER), 3(11), 118-124, 2014. Retrieved from https://d1wqtxts 1xzle7.cloudfront.net/3584 5127/N031101180124.pdf?1417860971= \&response-contentdisposition=inline $\% 3 \mathrm{~B}+$ filename $\% 3 \mathrm{DThe}$ _Trends_and_Tides_of_Poultry_Farm_Bui .pdf\&Expires $=1592095756 \&$ Signature $=B$ KI31FYucEQVe DUk1CGE iW1uShCTS 0KCGxt5TM7W415U3uEWDRfa 
CIGR. Report of working group on climatization of animal houses. Craibstone, Bucksburn, Aberdeen, Scotlant: Scotland Farm Buildings Investigation Unit, 1984. Retrieved from http://www.cigr.org/documents/CIGRWorkinggroupreport1984.pdf

CIRAD. Bilinga. 2012. Retrieved June 30, 2020, from

https://tropix.cirad.fr/FichiersComplement aires/EN/Africa/BILINGA.pdf

GATES, R. S.; ENNEKING, S. A.; XIONG, Y.; HESTER, P. Y.;

MAKAGON, M. M.; CHENG, H. W. Design and performance of cooled perches for alternative egg laying production systems. American Society of Agricultural and Biological Engineers Annual

International Meeting 2014, ASABE 2014, 4, 2909-2916, 2014.

https://doi.org/10.13031/aim.20141901235

GU, X. H.; LI, S. S.; LIN, H. Effects of hot environment and dietary protein level on growth performance and meat quality of broiler chickens. Asian-Australasian Journal of Animal Sciences, 21(11), 16161623, 2008.

https://doi.org/10.5713/ajas.2008.70395

HERBUT, P.; ANGRECKA, S.; NAWALANY, G.; ADAMCZYK, K. Spatial and temporal distribution of temperature, relative humidity and air velocity in a parallel milking parlour during summer period. Annals of Animal Science, 15(2), 517-526, 2015. https://doi.org/10.1515/aoas-2015-0001

HOLIK, V. Management of laying hens under tropical conditions begins during the rearing period. Lohmann Information, 50(2), 16-23, 2015.

JACOB, J. P.; WILSON, H. R.; MILES, R. D.; BUTCHER, G. D.; MATHER, F. B. Factors affecting egg production in backyard chicken. Animal Sciences Department, UF/IFAS Extension, University of Florida, (PS-35), 1-9, 2017.
Retrieved from

https://edis.ifas.ufl.edu/pdffiles/PS/PS0290 $0 . p d f$

JONES, T. A.; DONNELLY, C. A.; DAWKINS, M. S. Environmental and management factors affecting the welfare of chickens on commercial farms in the United Kingdom and Denmark stocked at five densities. Poultry Science, 84(8), 1155-1165, 2005. https://doi.org/10.1093/ps/84.8.1155

JONGBO, A. O. Evaluation of the environmental parameters of battery-caged poultry house in the humid tropical climate. Colombian Journal of Animal Science, 12(2), 2020.753, 2020.

https://doi.org/10.24188/recia.v12.n2.2020 .753

JONGBO, A. O.; FALAYI, F. R. Effect of some environmental variables on development of broilers in humid tropical environment. Projournal of Agricultural Science Research, 1(1), 1-6, 2013.

LOWEN, A. C.; MUBAREKA, S.; STEEL, J.; PALESE, P. Influenza virus transmission is dependent on relative humidity and temperature. PLoS Pathogens, 3(10), 1470-1476, 2007. https://doi.org/10.1371/journal.ppat.00301 51

MENCH, J. A. Introduction: Topical issues in poultry welfare. Advances in Poultry Welfare, xv-xix, 2018. https://doi.org/10.1016/B978-0-08100915-4.00026-9

MIKULSKI, D.; CELEJ, J.; JANKOWSKI, J.; MAJEWSKA, T.; MIKULSKA, M. Growth performance, carcass traits and meat quality of slowergrowing and fast-growing chickens raised with and without outdoor access. AsianAustralasian Journal of Animal Sciences, 24(10), 1407-1416, 2011. https://doi.org/10.5713/ajas.2011.11038

PEDERSEN, S.; TAKAI, H.; JOHNSEN, 
J. O.; METZ, J. H. M.; GROOT

KOERKAMP, P. W. G.; UENK, G. H.; ...

WATHES, C. M. A. comparison of three balance methods for calculating ventilation rates in livestock buildings. Journal of Agricultural and Engineering Research, 70(1), 25-37, 1998.

https://doi.org/10.1006/jaer.1997.0276

Poultry production. 2013. Retrieved June 30, 2020, from

https://www.agriculturenigeria.com/produ ction/livestock/poultry-production/

RIBER, A. B.; VAN DE WEERD, H. A.; DE JONG, I. C.; STEENFELDT, S.

Review of environmental enrichment for broiler chickens. Poultry Science, 97(2), 378-396, 2018.

https://doi.org/10.3382/ps/pex344

SCHAUBERGER, G.; MIKOVITS, C.;

ZOLLITSCH, W.; HÖRTENHUBER, S.

J.; BAUMGARTNER, J.; NIEBUHR, K.;
... SCHÖNHART, M. Global warming impact on confined livestock in buildings: efficacy of adaptation measures to reduce heat stress for growing-fattening pigs. Climatic Change, 156(4), 567-587, 2019. https://doi.org/10.1007/s10584-01902525-3

TEYE, F. K.; HAUTALA, M.; PASTELL, M.; PRAKS, J.; VEERMÄE, I.;

POIKALAINEN, V.; ... AHOKAS, J. Microclimate and ventilation in Estonian and Finnish dairy buildings. Energy and Buildings, 40(7), 1194-1201, 2008. https://doi.org/10.1016/j.enbuild.2007.10.0 17

WONG, J. T.; DE BRUYN, J.; BAGNOL, B.; GRIEVE, H.; LI, M.; PYM, R.; ALDERS, R. G. Small-scale poultry and food security in resource-poor settings: A review. Global Food Security, 15(March), 43-52, 2017.

https://doi.org/10.1016/j.gfs.2017.04.003 